\title{
Research on Zhengzhou City Image Construction Based on Local Culture
}

\author{
Kerang Zhao \\ Huanghe Science and Technology College \\ Zhengzhou, China
}

\begin{abstract}
City image is the comprehensive manifestation of intrinsic implication and external characteristics of a city, and embodiment of city development principle and city spirit. As the basic driving force of city development, it can generate exciting force internally and generate attraction externally. But most constructions of city image in our country lack individual characteristics. Therefore, it is necessary to put forward research on city image construction of Zhengzhou based on local culture, bring the thinking method, design measures of city planning and environmental design into the construction of city image to make characteristics of city image of Zhengzhou more prominent and distinctive.
\end{abstract}

Keywords-local culture; city image construction; research

\section{INTRODUCTION}

The development of urbanization increases the competition among cities. In order to seek for sound and rapid development and stand out from many cities, the development of modern city has not only emphasized the development of hard powers such as economic power, advantages of labor force and infrastructures, but also increasingly highlighted the competition of soft powers such as urban characteristics and urban culture. It makes the theoretical research and practical exploration of city image in our country deepened continuously and the construction of city image receive unprecedented attention. This article takes Zhengzhou as an example, takes local culture of the city as the starting point to research city image construction, endeavor to reveal the interaction effect of local culture and city image construction, explore the important strategic importance of local culture in city image construction, put forward the new concept and new path of city image design under the perspective of local characteristics, and form reference basis that guides the city image design and urban planning and construction.

\section{RELEVANT CONCEPTS OF CITY IMAGE CONSTRUCTION}

\section{A. City Image}

City image is the intuitive reflect of inner quality and cultural connotation of a city on external form, and the deep impression of this city that makes it different from other cities.
The construction of city image is the planning layout and design of various elements in urban organization structure and interrelations among them, especially the prominent characteristics. It not only includes the shaping of macro urban spatial structure, but also includes the design of micro image logo of cities.

\section{B. Local Culture}

Local culture includes historical context, folk custom and traditional culture, etc. It refers to the original and nativeborn culture and the local characteristics formed after the localization of foreign culture, which have rich local color and historical inheritance, can integrate history and modern civilization and embody local humanity and natural features. Local feature shows strong cultural root and a kind of warm and familiar natural environment; it also maintains the purity of native culture.

\section{Relationship Between Local Culture and City Image}

There is a mutual promoting relationship between local culture of cities and city construction. The construction of city image can promote the healthy and rapid development of urban construction, and the degree of urban construction also can react upon the establishment of urban cultural image. In the construction of modern city, it plays an extremely important role in increasing the characteristics and charm of cities, promoting urban competitiveness, improving living environment and urban life quality through deeply researching urban culture, excavating cultural resources and highlighting cultural advantages.

\section{RESEARCH ON CITY IMAGE CONSTRUCTION OF ZHENGZHOU BASED ON LOCAL CULTURE}

\section{A. City Image Construction of Zhengzhou-Characteristic Construction of Mind Imaging}

The most application of city orientation of Zhengzhou is always the "Green City". It is because the urban greening rate of Zhengzhou is very high and it has reached the standard of national garden city. Urban mind image is the central symbol of city image system, which mainly includes the position of city's properties, position of city's integral image, position of city brand, strategic position of city development. 
Position of city's properties: Zhengzhou, the capital of Henan province, the political, economic and cultural center of Henan province, an important key city in the central region of our country, the national important hub of comprehensive transportation and communication, the national famous historical and cultural city.

Position of city's integral image: Zhengzhou, national central city of urban image position, core city of Central Plains Economic Zone, and key city of Zhengzhou metropolitan area.

Strategic position of city development: Zhengzhou, national central city, strategic fulcrum of national economic layout, the demonstration area for coordinated and scientific development of "new industrialization, new urbanization and agricultural modernization", world-famous cultural city, international inland port, international air harbor, core growth region of Central Plains Economic Zone. Combining with the strategic planning, further confirm the position of the development of Zhengzhou metropolitan area is "one region and three cities", namely national central city, international aerotropolis, world-famous cultural tourism city and the core growth region of Central Plains Economic Zone.

Position of city brand: Zhengzhou, national central city, international aerotropolis, world-famous cultural tourism city, the core growth region of Central Plains Economic Zone.

The strategic position of city development of Zhengzhou is the important content of urban mind image, and also the key factor that concerns city development and enthusiasm of city behavior.

\section{B. City Image Construction of Zhengzhou-Characteristic Construction of Cultural Image}

Urban culture is the aggregation of material civilization and spiritual civilization created by human in the process of progress, and the comprehensive reflection of a city's image. The reproduction and accumulation of history form specific cultural potential energy, place effect and customs and mentality of an area and constitute the unique spirit and temperament of this area. Scenic spots and historic sites are important carriers of history and culture.

The first is cultural remains. Zhengzhou is located in the central plains. In the areas under its administration, it has been found that there is Peiligang culture, which is 8,000 years before present, relics of Yangshao culture and Longshan culture such as Dahe village, Qinwangzhai, which are 5,000 years before present. The cultural influence of them is not confined to Henan province. It is of great importance in the whole central plain culture, even the culture in Yellow River basin and Shang dynasty-capital culture. All of these constitute the unique historical and cultural image of Zhengzhou.

The second is cultural development. Zhengzhou is one of the eight ancient capital cities in China and the member of "the League of Historical Cities". Before liberation, "the Great Strike of February 7, 1923" happened in Zhengzhou writes a glorious page in the history of Chinese working class movement. In memory of the great strike, "Erqi" memorial hall is built at the site-memorial of the federation of Beijing-Hankou railway workers' trade unions; in the downtown, there are "Erqi" square and "Erqi" Memorial Tower. Long history and important traffic position make Zhengzhou have incontrovertible and important historical and cultural status.

The third is religious culture and natural culture. Natural scenery and colorful religious culture represented by Songshan Shaolin, and tourist spots represented by Songshan scenic spot, Yellow River tourism spot, scenic spot of Mount Fuxi, Guandu Ancient Battlefield tourist area, etc. are symbols and embodiments of cultural deposits of Zhengzhou.

The fourth is folk culture and diet culture. Zhengzhou has inherited and developed a large number of folk cultures, and also has generated and inherited Henan Opera, one of the five operas in China. The hold of Liyuanchun program also boosts the development of folk Henan Opera. In 2006, Henan Opera is included in the first batch of state-level intangible cultural heritage list by the State Council. Meanwhile, the diet culture of Zhengzhou also has a distant origin and a long development. The national famous Zhengzhou stewed noodles, chewy and elastic, with special soup and ingredients, can leave us with endless aftertastes. It is one of the images of city brand of Zhengzhou.

The ancient and profound cultural deposits of Zhengzhou are always the important propaganda points that we publicize. Today, with the rapid development of service industry and the drive of industry with local characteristics, the spread of city image of Zhengzhou will be wider and the influence will be more profound.

\section{City Image Construction of Zhengzhou-Characteristic Construction of Behavior Image}

Civilized image of a city is indirectly manifested in the behavior of citizens. Except for constructing urban planning, the government of Zhengzhou also needs to guide citizens to set up good city image and guide all the citizens to participate to embody the broad mind of Zhengzhou people and harmonious urban spirit. In the city image construction of Zhengzhou, the characteristic of behavior image is particularly important. No matter government image, citizens' image or window image, they are means to promote the city's comprehensive competitive power and highlight civilized city. Therefore, in the city image construction of Zhengzhou, we should highlight the construction of behavior image.

\section{City Image Construction of Zhengzhou-Characteristic Construction of Visual Image}

According to the establishment of urban spirit and city positioning of Zhengzhou, the visual image of Zhengzhou should be constructed by completely centering on the position of "Green City", make people feel the uniqueness and freshness everywhere brought by "Green", and manifest the broad, open, innovative and harmonious cityscape brought by Zhengzhou city. It should be easy for people to recognize and feel the interior quality of Zhengzhou. 
TABLE I. DESIGN ELEMENTS OF City IMAGE VI System

\begin{tabular}{|l|l|}
\hline \multicolumn{2}{|c|}{ Design elements of city image VI system } \\
\hline City name & Collection of city flower and city tree \\
\hline Logotype of city name & City image ambassador \\
\hline City landmark & City color design \\
\hline City badge & Design of flag and guideboard \\
\hline City standard color & Design of tourism city sign \\
\hline City symbols & Series of transportation means \\
\hline $\begin{array}{l}\text { City propaganda slogan and } \\
\text { banner design }\end{array}$ & Landscape logo design \\
\hline City sign systems design & Design of advertising communication \\
\hline
\end{tabular}

It can be concluded from "Table I" that we can construct city image VI system and finally achieve the objective of "dynamic Zhengzhou, happy metropolis".

\section{E. City Image Construction of Zhengzhou-Characteristic Construction of Ecological Image}

The natural environment is the inherent characteristics of a city. Using the unique natural environmental characteristics of a city and the systematic organization of urban landscape can make them become the city image that has typical significance. The city image construction of Zhengzhou should also find individual characteristics in ecological image to build national ecological city and national garden city. Mainly start from the following two aspects:

Firstly, strengthen the construction of green vein and make characteristic space of landscape pattern. Within the scope of administrative region, strengthen the construction of "green vein". One is relying on the mountain chain of Songshan, and the other is the large "green vein" in east-west direction that relies on the water vein of Yellow River. Within the scope of downtown, strengthen the shaping of green space structural feature, strive to form distinctive natural landscape pattern. Secondly, pay attention to the characteristics of urban spatial layout. On urban spatial layout, we should give full play to the characteristics of Zhengzhou city on urban spatial layout, strengthen the present spatial structure characteristics of "two axes and one belt, seven districts and multiple centers", and strengthen the construction of green corridor in city center.

To sum up, the city image construction should attach importance to inheritance as well as innovation. City image is a compound system. Characteristic is the "name card" of city. Only by relying on local characteristics can we improve city image.

\section{STRATEGIC ASSUMPTION OF CITY IMAGE CONSTRUCTION OF ZHENGZHOU}

Urbanization process develops sharply. Some acknowledged world cities pay more and more attention to the special function of culture in promoting the development, successively put forward series of new demands and new objectives that strengthen the city's competitiveness from the perspective of urban future development. Aiming at the present city image construction of Zhengzhou city, it is necessary to combine with the characteristics of Zhengzhou, try to explore the strategic conception of city image construction of Zhengzhou.

\section{A. Dynamic Zhengzhou, Happy Metropolis}

Build a garden city that "mountain, water, field, forest and city" have integrative development; protect and sort cultural heritage, build five historical and cultural areas: Zhengzhou Shangdu, Historic Monuments of Mount Songshan, Han Culture in Guxing, Birthplace of Emperor Huangdi, and Heluo Culture. Inherit and renovate Chinese historical civilization, spare no efforts to promote the international influence of cultural brand image and strengthen competitive power of culture; realize the change of system of metropolitan area from "restrictions to promotion", and build innovative city.

\section{B. Metropolis of Chinese Trade Culture}

Zhengzhou has won the laudatory title of "Shangdu" since ancient times. The economy is prosperous and the trade contacts are frequent. It is the birthplace of Chinese market competition in $20^{\text {th }}$ century. Except for the prosperous Erqi business district, the development of Erqi Wanda business district, Zhongyuan Wanda business district, CBD business district in Zhengdong New District, Yinji commerce and trade business district, tax-protected zone in air harbor also change with each passing day. Trade culture can be considered as a core outline that leads the development of Zhengzhou. Therefore, the overall brand positioning of "the capital of Chinese trade culture" conforms to the development status and brand advantage of Zhengzhou.

\section{Famous City of Chinese MICE Tourism}

Zhengzhou has certain foundation on convention and exhibition and tourism. Especially it points out in the Outline of "Twelfth Five-Year" Plan of Zhengzhou that the development of convention and exhibition of Zhengzhou should "stick to the principles of specialization, marketization, and internationalization and branding, intensify policies support, expand the space and scale of the development of conference and exhibition industry and build conference and exhibition metropolis in China." Therefore, for the realization of value of Zhengzhou tourism function, on one hand, we should continuously excavate local resources and optimize the configuration of tourism industrial chain; on the other hand, we can use convention and exhibition function to drive and stretch the industrial chain of convention and exhibition and achieve integrative development with tourist industry. The objective system of city MICE brand of Zhengzhou is "keep a foothold in Central China, radiate to the whole nation and face the world".

\section{Metropolis of Chinese Traditional Culture}

In order to better support the functional brand of convention and exhibition and tourism functional brand that the history and the modern coexist and combine with each other, Zhengzhou should hold convention and exhibition of local brands that have enough influences. Take the history and culture in Central Plains, culture of family name, and Chinese culture of earliest ancestor, Shaolin Wushu culture as carriers; consolidate brand activities such as "the Grand Ceremony of Worship of Ancestors in the Birthplace of 
Huangdi Emperor", “the International Shaolin Martial Arts Festival", make Zhengzhou become international center of festival activities.

\section{E. Metropolis of Chinese Logistic Hub}

In March 7, 2013, the Development Planning of Zhengzhou Airport Economic Comprehensive Experimental Zone (from 2013 to 2025) obtained formal approval of the State Council. It brings excellent development opportunity for Zhengzhou and even Henan province, and means that Zhengzhou Airport Economic Comprehensive Experimental Zone becomes the first going-first area of airport economic development that is included in national strategy. In order to construct Zhengzhou into a metropolis of modern logistic hub, it's essential to guide the gathering of modern logistic enterprises, boost modern logistic enterprises to carry out multimodal transport and container transportation, promote the interactive development of modern logistic enterprises and processing and manufacturing and circulation industry, make investments to build public information platform of modern logistics and construct Zhengzhou air harbor into the Memphis in China.

\section{CONCLUSION}

City image has become essential means of city development and strategic problem that must be solved. This article does systematic research on the theory and practice of city image, bases on the perspective of local characteristics, discusses the system connotation of city image, and starts from the spatial construction of city image to analyze characteristics of city image. Through comprehensive analysis of city image of Zhengzhou city, it is hoped that city image construction with local features can bring the construction of Zhengzhou city into a track of virtuous cycle of sustainable development strategy, and provide referential system thinking and feasible operating approaches for city image construction of the whole Henan province.

\section{REFERENCES}

[1] Zhang Hongyan. Discussion on City Image and City Cultural Capital - the Study of Sociology by Comparing Chinese and Foreign City Images [M], Nanjing: Southeast University Press, 2002.8

[2] (America) Kevin Lynch, City Image [M], Beijing: Huaxia Publishing House, 2001.4

[3] Translated by Lewis Mumford, Song Junling, etc. History of Urban Development-the Origin, Evolution and Prospects [M], Beijing: China Architecture and Building Press, 1989

[4] Zhang Minxia. Primary Investigation on the Construction of City Tourism Image - Concurrent Discussion on the Construction of Tourism Image of Xi'an City [D], Xi' an University of Architecture and Technology, 2004

[5] Zhu Yuming, Yin Qingzhong. Theory and Practice of Promotion of City Image-Taking Jinan City as an Example [J], the Journal of the Party School of CPC Jinan Municipal Committee Jinan City College of Administration and Jinan City Academy of Socialism, 2004.4

[6] Lv Wenqiang. Design of City Image [M], Nanjing: Southeast University Press, 2002 